\title{
BERBAGI BERSAMA UNTUK 30 WARGA YANG TERDAMPAK COVID-19 KELURAHAN BABAKAN. KOTA TANGERANG SELATAN, PROVINSI BANTEN
}

\author{
Asep Suherman, Syarifah Ida Farida, Teguh Yuwono, Surasni, Achmad Sumali \\ Universitas Pamulang \\ Email: asep83alil@gmail.com
}

\begin{abstract}
In our Community Service activities we collaborated with the Head of the Rt 04/03 Environment in the Babakan area in South Tangerang, South Sulawesi. This was done to prevent the spread of Covid-19 in the surrounding area. Banten is a province that is increasingly rising this Pandemic case, so the issuance of Regional Regulations on Large-Scale Social Restrictions. Tahanpan provided assistance and dissemination of the first thing done in the distribution of basic food items, all basic food items were stored in the house of the neighborhood leader, after all were collected, we distributed all the food items to the houses of residents affected by covid-19, according to data provided by the head of RT 04 / 03 for 30 people affected by covid 19 After distribution of nine-basic necessities for 30 residents in Rt. 04/03, we provide socialization and education with the aim of making people aware and understanding the importance of washing their hands using running water and soap or hand sanitizers, close the nose when colds and close the mouth when sneezing and coughing by using a handkerchief or tissue, avoiding shaking hands, avoiding crowds (as much as possible at home) and maintaining physical distance (physical distancing), and don't forget to wear a mask
\end{abstract}

Keywords: Benefits, Residents, Impacts, Covid-19

\begin{abstract}
Abstrak
Dalam kegiatan Pengabdian Kepada Masyarakat kami melakukan kerjasama dengan Ketua Lingkungan Rt 04/03 di daerah Babakan setu tangerang selatan..Berdasarkan peraturan pemerintah Pusat dan Pemerintah Daerah Banten dikarenakan adanya Pandemi Covid-19 warga dilarang keluar rumah. Hal ini dilakukan untuk mencegah penyebaran Covid-19 di daerah sekitarnya. Banten merupakan provinsi yang semakin naik kasus Pandemi ini, sehingga dikeluarkannya Peraturan Daerah mengenai Pembatasan Sosial Berskala Besar. Tahanpan memberikan bantuan dan sosialisasi hal yang pertama dilakukan dalam pendistribusian sembako,
\end{abstract}


semua sembako di simpan di rumah ketua lingkungan, setelah semua terkumpul, kami mendistribusikan semua sembako ke rumah-rumah warga yang terdampak covid-19, sesuai data yang diberikan oleh ketua RT 04/03 untuk 30 warga yang terdampak covid 19 Setelah dilakukan penyaluran sembako untuk 30 warga dilingkungan Rt 04/03, kami memberikan sosialisasi dan edukasi dengan tujuan ikut menyadarkan dan memberikan pengertian kepada warga mengenai pentingnya mencuci tangan dengan menggunakan air yang mengalir dan sabun atau hand sanitizer, menutup hidung saat pilek dan menutup mulut saat bersin dan batuk dengan menggunakan sapu tangan atau tisu, menghindari berjabat tangan, menghindari keramaian (semaksimal mungkin berada di rumah) serta menjaga jarak fisik (Phisical Distancing), dan jangan lupa untuk memakai masker.

Kata Kunci: Santunan, Warga, Dampak, Covid-19

\section{A. PENDAHULUAN}

Coronavirus merupakan virus RNA strain tunggal positif, berkapsul dan tidak bersegmen. Coronavirus tergolong ordo Nidovirales, keluarga Coronaviridae. Coronaviridae dibagi dua subkeluarga dibedakan berdasarkan serotipe dan karakteristik genom. Terdapat empat genus yaitu alpha coronavirus, betacoronavirus, deltacoronavirus dan gamma coronavirus.

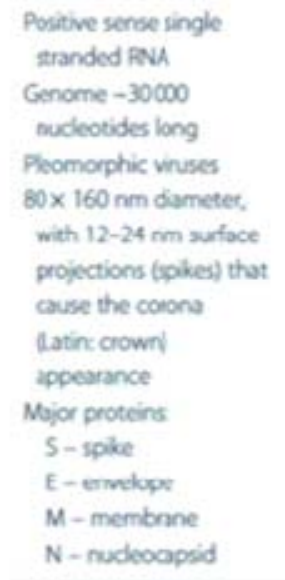

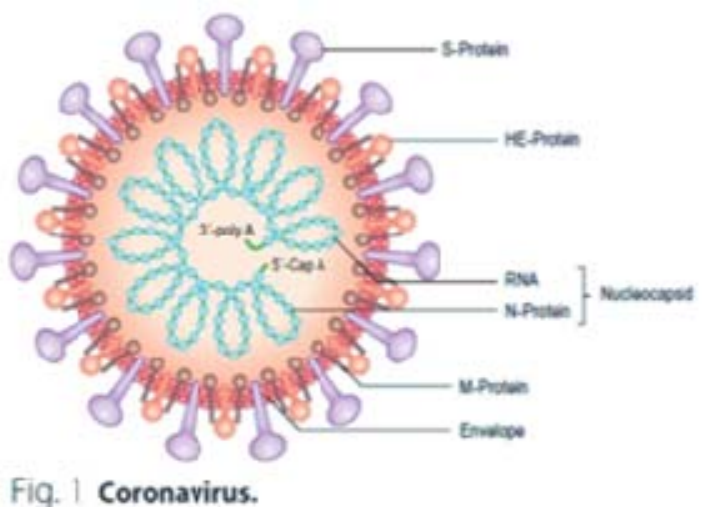

Fig. 1 Coronavirus.

\section{Gambar 1. Struktur Coronavirus}

Virus yang mematikan ini menyebar dengan cepat di seluruh Negara di Dunia, tanpa terkecuali Indonesia termasuk salah satunya. Indonesia merupakan Negara terbesar di Asia tenggara karena jumlah penduduknya, sehingga saat virus Covid-19 sudah masuk ke Indonesia dengan cepat menyebar hampir di seluruh provinsi. DKI Jakarta yang terbanyak 
mengalami korban Covid-19, sudah banyak yang meninggal dunia disebabkan oleh virus ini, juga di provinsi lain di Indonesia antara lain Jawa Timur, Jawa Barat, Jawa Tengah, dan provinsi lainnya.

DKI Jakarta mengalami banyak kemunduran ekonomi saat terkena dampak Covid-19 ini, begitu juga dengan kota kecil disekitarnya antara lain Depok, Bekasi, Bogor, Tangerang, termasuk Tangerang Selatan. Seakan lumpuh perekonomian Indonesia di segala lini diakibatkan dampak Covid-19 ini. Perusahaan, Mall, Sekolah, Universitas, dan pasar-pasar besar sementara di tutup. Perkantoran juga ditutup dan dilakukan Work From Home (WFH) atau bekerja dari rumah, karena diberlakukannya Pembatasan Sosail Berskala Besar (PSBB) oleh Pemerintah Indonesia. Banyak para pedagang dan pegawai yang terkena dampak sangat drastis. Penghasilan menurun, pegawai banyak yang di PHK dimulai dari bulan Maret 2020.

Melihat situasi ini, kami tergerak untuk membantu masyarakat di sekitar kampus Universitas Pamulang, yaitu di RT 04/03 Babakan Setu Tangsel. Kami membantu mereka karena terkena dampak adanya pandemi Covid-19. Warga RT 04/03 Babakan Setu Tangsel ada yang terdampak tidak punya penghasilan karena berhenti berdagang dan ada juga yang di PHK oleh perusahaan tempat mereka bekerja. 30 warga dipilih oleh kelompok PKM Prodi Manajemen dan Akuntansi D3 Fakultas Ekonomi Universitas Pamulang. Tim PKM yang diketuai oleh Asep Suherman, SE, MM, dengan anggota Syarifah Ida Farida, SE, MM, Teguh Yuwono, SE, MM, Dr Surasni, M.Pd, dan Achmad Sumali, M.Pd.

Mungkin hanya sebagian kecil pengaruh yang ditimbulkan untuk warga Indonesia saat pandemi seperti ini. Tapi bagi warga Setu Babakan sangat dirasakan manfaatnya sumbangan kami untuk 30 warga yang tekena dampak Covid-19. Mereka sangat merasakan tekanan hidup yang sangat berat tanpa bisa berbuat apa-apa dikarenakan situasi yang mengharuskan mereka tetap tinggal di rumah dengan segala peraturan untuk hidup bersih dan menjalani protokol kesehatan yang ketat.

\section{B. METODE PELAKSANAAN KEGIATAN}

Metode kegiatan pengabdian ini adalah 30 warga yang terdampak covid 19 dilingkungan babakan setu. Metode kegiatan ini dilakukan dengan tim PKM Dosen Universitas Pamulang mendatangi kelurahan dan ketua lingkungan Rt 04/03 babakan setu, kemudian diberikan bantuan sembako ke rumah-rumah warga yang terdampak covid 19.

Persiapan Kegiatan Pengabdian pada Masyarakat. Sebelum kegiatan dilaksanakan maka dilakukan persiapan-persiapan sebagai berikut:

1. Datang ke Kelurahan dan Ketua Lingkungan RT 04/03 Babakan setu untuk mengkomunikasikan masalah penyaluran sembako pada saat pengabdian kepada masyarakat.

2. Menentukan waktu pelaksanaan dan lamanya kegiatan pengabdian bersama-sama tim pelaksana.

3. Melakukan persiapan kebutuhan sembako dan barang-barang yang akan di beli.

4. Sosialisasi dan menyalurkan sembako yang akan disampaikan dalam kegiatan pengabdian masyarakat 
Tahapan kegiatan PKM ini dapat dijelaskan melalui Gambar berikut ini :

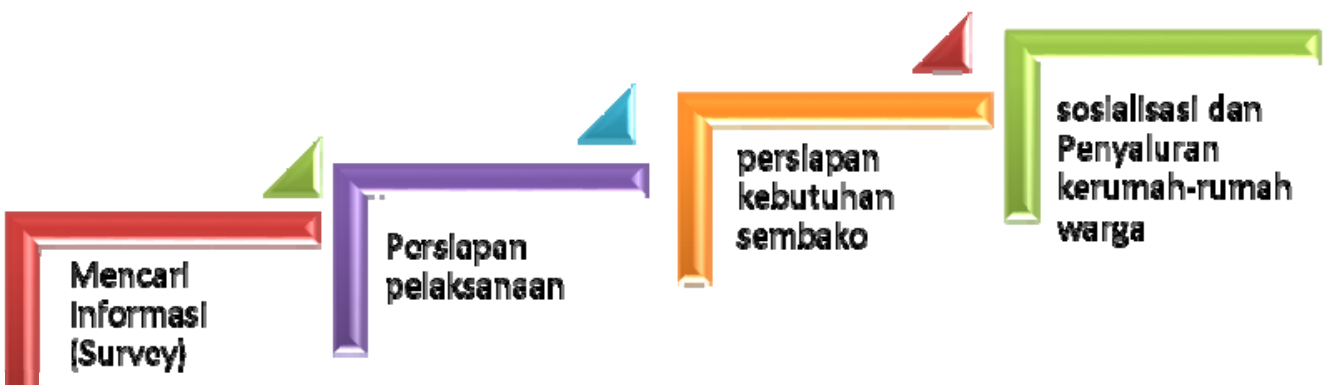

Gambar. 2. Tahapan Kegiatan PKM

\section{HASIL DAN PEMBAHASAN}

Keberhasilan kegiatan pengabdian kepada masyarakat salah satunya dapat dilihat dari hasil evaluasi apakah terjadi respon warga setelah dilakukan kegiatan ini. Hasil kegiatan PKM ini dapat dijelaskan sebagai berikut :

Tahapan awal kami melakukan kerjasama dengan Ketua Lingkungan Rt 04/03 di daerah Babakan setu tangerang selatan. Berdasarkan peraturan pemerintah Pusat dan Pemerintah Daerah Banten dikarenakan adanya Pandemi Covid-19 warga dilarang keluar rumah. Hal ini dilakukan untuk mencegah penyebaran Covid-19 di daerah sekitarnya. Hal ini sangat berdampak untuk warga yang berstatus janda, fakir miskin, yatim dan berhenti berkerja/berdagang. Dari hasil survey dan wawancara melalui Ketua RT babakan setu tangerang selatan bahwa ada 30 warga yang didaerah perkampungan babakan setu tidak mendapatkan penghasilan, ada yang berhenti berkerja karena di PHK ada juga yang berhenti berdagang karena tidak boleh keluar rumah, dan ada juga janda, fakir miskin, dan yatim yang perlu dibantu.

Tahanpan memberikan bantuan dan sosialisasi untuk tahapan memberikan sosialisasi dalam bentuk sembako ini. Kami berkerjasama dengan ketua lingkungan dan dosen universitas pamulang untuk memberikan bantuan, hal yang pertama dilakukan dalam pendistribusian sembako. Semua sembako di simpan di rumah ketua lingkungan, setelah semua terkumpul, kami mendistribusikan semua sembako ke rumah-rumah warga yang terdampak covid-19, sesuai data yang diberikan oleh ketua RT 04/03 untuk 30 warga yang terdampak covid 19. Setelah dilakukan penyaluran sembako untuk 30 warga dilingkungan RT 04/03 kami memberikan sosialisasi dan edukasi dengan tujuan ikut menyadarkan dan memberikan pengertian kepada warga mengenai pentingnya mencuci tangan dengan menggunakan air yang mengalir dan sabun atau hand sanitizer. Menutup hidung saat pilek dan menutup mulut saat bersin dan batuk dengan menggunakan sapu tangan atau tisu, menghindari berjabat tangan, menghindari keramaian (semaksimal mungkin berada di rumah) serta menjaga jarak fisik (Phisical Distancing), dan jangan lupa untuk memakai masker.

\section{KESIMPULAN DAN SARAN}

Kesimpulan dari hasil PKM kegiatan berbagi untuk 30 warga yang terdampak covid 19, semua warga sangat senang dan berterima kasih pada dosen universitas pamulang. Dari hasil 
PKM dapat disimpulkan bahwa Berdasarkan hasil pelaksanaan kegiatan pengabdian kepada masyarakat oleh lingkungan dan Dosen Universitas Pamulang di lingkungan babakan setu. Tangerang Selatan adalah sebagai berikut:

1. Warga sangat membutuhkan bantuan terutama untuk warga yang terdampak covid 19.

2. Untuk membantu warga yang terdampak covid-19 perlu adanya dukungan dari Pemerintah.

3. Perlunya data warga yang membutuhkan bantuan akibat dampak covid-19 dan perlunya kesadaran warga atas bahaya virus corona dari Kelurahan

\section{DAFTAR PUSTAKA}

Asep Suherman, (2020, Juli 20) https://www.bantennews.co.id/dampak-covid-19-berdoa-dan bersabarlah/?fbclid=IwAR3vEjEaOvCSLId8wx4n2ajECpveoGeggFAcPiuTsDetKHRfUb b8vETBac.

Dalam Rangka Percepatan Penanganan Corona Virus Disease 2019 (COVID 19).

Farida, S. I. (2020, Juni 5). rakyatmerdekanews.com. Diambil kembali dari rakyatmerdekanews.com: https://rakyatmerdekanews.com/2020/06/05/cara-bertahanhidup-di-masa-pandemi-covid-19/.

Farida, S. I., Iqbal, M., \& Kurniasih, A. (2016). Pengaruh Kepercayaan Dan Komitmen Organisasi Terhadap Motivasi Kerja Serta Implikasinya Pada Kepuasan Kerja. Jurnal Kependidikan: Penelitian Inovasi Pembelajaran, 46(1), 121-134.

Farida, S. I. (2018). Anggaran responsif gender sebagai suatu instrumen negara untuk pemenuhan hak perempuan di Indonesia. JIMF (Jurnal Ilmiah Manajemen Forkamma), $1(2)$.

Farida, S. I., Prasetiyani, D., Safiih, A. R., Prasada, D., \& Ismanto, B. (2020). Pelatihan SDM: Usaha Konvensional menjadi Usaha Digital. Jurnal Abdi Masyarakat Humanis, $1(2)$.

Farida, S. I., \& Anjani, S. R. (2019). Menumbuhkan Jiwa Kepemimpinan Pada Mahasiswa di Lingkungan Universitas Pamulang. INOVASI, 6(2), 19-20.

Farida, S. I., \& Khair, O. I. (2019). Leadership sebagai Dasar Kecerdasan Intelektual Mahasiswa Program Studi Manajemen di Universitas Pamulang. JIMF (Jurnal Ilmiah Manajemen Forkamma), 3(1).

Surat Keputusan Menteri Kesehatan Nomor HK.01.07 /Menkes/239/2020, tentang Penetapan Pembatasan Sosial Berskala Besar di Wilayah Provinsi DKI Jakarta.

Surat Edaran Nomor 2 Tahun 2020 tentang Pencegahan dan Penanganan COVID-19 di Lingkungan Kemendikbud.

Keputusan Presiden Republik IndonesiaNomor 11 tahun 2020 Tentang Penetapan Kedaruratan Kesehatan Masyarakat Corona Virus Disease 2019 (Covid- 19). 